\title{
A Critical Legal Study of the Declaration of the Rights of Man and of the Citizen
}

\author{
Shuresh Moradi* \\ Tsinghua School of Law, Beijing, China \\ Email: Shuresh.mor@gmail.com
}

How to cite this paper: Moradi, S. (2019). A Critical Legal Study of the Declaration of the Rights of Man and of the Citizen. Beijing Law Review, 10, 1137-1171. https://doi.org/10.4236/blr.2019.105061

Received: June 18, 2019

Accepted: October 11, 2019

Published: October 14, 2019

Copyright $\odot 2019$ by author(s) and Scientific Research Publishing Inc. This work is licensed under the Creative Commons Attribution International License (CC BY 4.0).

http://creativecommons.org/licenses/by/4.0/ (c) (i) Open Access

\begin{abstract}
This paper aims to examine and analyse from the perspective of Critical Legal Studies whether, and to what extent, the concept of law relates to the economic structure of society. Furthermore, the aim is to shed light on the potential problem of the perception and generation of legitimacy derived from economic interests. More precisely, this paper will investigate the relationship between the economic structure of the French society in 1789, the Declaration of the Rights of Man and the Citizen and the philosophy of the Enlightenment.
\end{abstract}

\section{Keywords}

Critical Legal Studies, Legal History, French Revolution, The Enlightenment, Ancien Régime

\section{Introduction}

\subsection{Topic and Objectives}

The legacy of the French Revolution is hard to overestimate. Indeed, it might be seen as the main force that came to shape the economic landscape and Continental philosophy. This essay focuses more narrowly, however, on the relationship between the economic structure of the French society in 1789, the Declaration of the Rights of Man and the Citizen and the philosophy of the Enlightenment. This interdisciplinary paper, drawing from jurisprudence, legal history as well as political and social sciences, aims to describe the historical events that culminated in the first year of the French Revolution of 1789, and the drafting of the Declaration of the Rights of Man and of the Citizens, as well as the material content of the Declaration and its source of legitimacy. In tackling these questions, the approach of Critical Legal Studies as well as the Classical ${ }^{*} \mathrm{PhD}$ Candidate. 
Historiographical School is adopted. The Classic Historiographical School resonates with Critical Legal Studies in terms of the latter's emphasis on a socio-economic interpretation, as well as the critical approach to the unequal distribution of wealth and power. Moreover, a theoretical approach in describing the relationship between the law, with a focus on the Declaration of the Rights of Man and the Citizens, the economic structure and the centralization of wealth in 1789, and the role of philosophy derived from the Enlightenment is used.

The scope of this paper is limited to the events of the year 1789 in France. In order to further limit the extent of the paper, the approach of the Classic Historiographical School as well as the Critical legal approach regarding the events of the revolutionary period is adopted.

\subsection{Disposition}

The paper consists of five main parts followed by a final discussion and analysis. The first part aims to provide the historical basis for the analysis and discussion of the rest of the paper in order to give an understanding of the main historical events that culminated in the French Revolution in 1789. The description will be methodologically explained according to the Classic Historiographical School and Lefebvre's division of the French Revolution into distinct revolutionary events, beginning with the aristocratic revolution, followed by the bourgeois revolution, then the popular revolution, and finally, the peasant revolt and the march on Versailles.

The first part sets the basis for the second part where the main legal act of the revolution in 1789, namely The Declaration of the Rights of Man and Citizens, is presented. In the third part, the central characteristics of the philosophy of the Enlightenment are described. The fourth part introduces Critical legal studies and explains the central characteristics of the movement that are of importance to this paper. The paper concludes with the fifth part, where the final summary and conclusion are presented.

\section{The CLassic Historiographical School}

The statement history is written by the victors applies particularly with regards to the French Revolution. Research and writings on the revolutionary period in France have long mirrored the Classic Historiographical School, which have dominated the landscape of revolutionary historiography up until the 1960's.

This paper adopts the classic interpretation of the French Revolution, which is above all a social analysis of history (Heller, 2009). Among the modern scholars who advocate this view, George Lefebvre is considered one of the most outstanding. Lefebvre, Chair of the History of the French Revolution at the Sorbonne, specialized in agrarian history as well as the great political events of the French revolutionary era, emphasized the importance and necessity of a deeper analysis of the structural conditions that gave rise to a social revolution, as opposed to a merely political approach (Cobban, 1999). 
Those who adhered to the social interpretation recognized the movement that arose in 1789 as essentially bourgeois, albeit supported by the masses (Lefebvre, 1962; Heller, 2009). The Classic Historiographical School recognizes the bourgeois led movement as the political foundation for the new economic system that followed as a result of the French Revolution. Furthermore, the Classic Historiographical School sheds light on what they perceived to be a conflict between the feudal system and the new market economic structure, which was essentially determined by the progressive bourgeoisie. ${ }^{1}$ Moreover, the Classic historiographical school presents a scepticism towards the division of power and the socio-economic structure of society corresponding to the fundamental principles of Critical Legal studies.

\section{The Historical Developments}

It is of importance to recognize that the French Revolution refers to the various stages of a process that spanned a period of 10 years. The historical developments of the French regime that I will focus on are primarily the events of the year 1789, a period characterized by the ascension of the bourgeoisie. During this period, the revolution in France erupted as a consequence of the existing contradictions between the archaic feudal regime and the nascent capitalist regime.

The events that led to the bourgeoisie's seizure of political power in France, present a good starting point to analyze the emergence of the bourgeois state, as it was the first bourgeois state to emerge in entirely revolutionary conditions. The investigation and analysis here will be conducted mainly from the perspective of Lefebvre who deconstructs the French Revolution by identifying four separate interest groups, and four revolutions, all of which together constitute the French Revolution; the aristocratic revolution, the bourgeois revolution, the popular revolution, and lastly the peasant revolution.

\subsection{The Estates-General}

In the Ancien Régime, the feudal representative organ in the realm was a legislative assembly of the three Estates: the clergy, nobility and the Third Estate, together constituting the Estates-General. The estates voted by orders, which meant that each estate would have a collective vote and that these votes weighed equally (Lefebvre, 1988). Members of the nobility and clergy made up approximately five-hundred thousand of twenty-three million Frenchmen (Sée, 1925) and their ownership of land, tax exemption and their right to receive feudal dues were the main factors that led to their economically and socially privileged position in the Ancien Régime (Lefebvre, 1988). The clergy, a privileged group of

${ }^{1}$ Although great emphasis is put on the socio-economic analysis of history, one should tread carefully when attempting to characterize the Classic Historiographical approach as primarily Marxist or dogmatic, since the social interpretation became the official historiographical interpretation of the Third Republic, which was defended both by the liberal establishment as well as by prominent members of left-wing academia, despite their differences regarding class-distinction, social structures and liberal democracy. 
priests, bishops, abbots and vicars, kept their own administration and courts and were consequently relatively independent of the state (Lefebvre, 1988). Less favoured by the King, members of the nobility enjoyed privileges such as exemption from the direct taxation of land, la taille. However, as opposed to the clergy, they were obliged to pay certain taxes, such as a tax based on rank, la capitation, and an income tax, les vingtieme. The burden of these taxes was however questionable, as nobility already held an economically privileged status, especially in regards to the ownership of land (Lefebvre, 1988). However, maintaining their status was a costly effort, which was continuously increasing, as the inflation reduced the value of their rental revenues. Moreover, the nobility was barred from exercising commerce leaving them completely dependent on the value of their estates (Lefebvre, 1988). Furthermore, and much to the discontent of la noblesse d'épée, the King began to sell titles, often including positions in public office, to the wealthy bourgeoisie, who were then referred to as noblesse de robe (Lefebvre, 1988).

By the $18^{\text {th }}$ century, the economic gap between the two socio-economic groups, the aristocracy and the bourgeoisie, decreased as the increase of trade and commerce gave rise to an increasingly economically powerful bourgeoisie. Although members of the bourgeoisie, some of whom were financially stronger than the nobility and the clergy, did not, yet, constitute a threat to nobles or clergymen, they still held a dominant position in society. Eventually, the nobility became a considerably less homogenous socio-economic group as noblemen assumed various economic positions.

\subsection{The Aristocratic Revolution}

The economic structure in the world of 1789 was essentially agrarian (Hobsbawm, 1996). ${ }^{2}$ The last revolt of the aristocracy in France took place in the $17^{\text {th }}$ century, which essentially stripped the aristocracy of its political power and independence, and forced its submission to the Capetian dynasty (Lefebvre, 2005). However, the nobility and the clergy were able to hold on to their social and economic privileges, which essentially defined their role; while they were subordinate monarchical rule, they maintained a privileged status.

The causes of the French Revolution centered around the economy, which had become increasingly strained as a result of France's involvement in the American independence, not to mention court expenditures, the costs of army and navy upkeep, and diplomacy (Lefebvre, 1988; Hobsbawm, 1996). Attempts to cut the deficit by increasing the already high taxes of the non-privileged were insufficient, and only agitated the people who suffered these consequences. Therefore, a proposition was made to further tax all landowners regardless of their privileges, which consequently resulted in a strong reaction against the monarch. It was in this context that the aristocracy saw their opportunity to regain the political power they had given up under the rule of Louis XIV. For the

\footnotetext{
${ }^{2} \mathrm{~A}$ year before the revolution, the budget deficit amounted to at least 20 per cent of the expenses.
} 
first time since 1614, the Estates-General assembled, resulting in the unanimous vote to strip the King Louis XVI from his power (Lefebvre, 1988).

As a result of these events, referred to as the Aristocratic Revolution, the bourgeoisie came to believe in their own ability to undermine the power of both the clergy and the nobility, paving the way for the Bourgeois Revolution that would mark the collapse of the Ancien Régime. The inevitability of this collapse becomes all the more apparent, as the clergy and nobility, while desperately clinging to their birth right, prevented necessary reforms.

\subsection{The Third Estate}

The Third Estate was a legal unity in the Estates-General that represented the vast majority of the French population. It incorporated "the wealthiest bourgeois to the poorest beggar" (Lefebvre, 2005). However, a clear majority of the representatives of the Third Estate were legal scholars, who were financially secure, and who held prominent positions.

The resistance against the absolute monarchy had united the three Estates. The main goal was to create a new legislation and introduce taxation reforms. What divided the Estates was their own role and position in relation to the state. The bourgeois who dominated the Third Estate, influenced by the ideas of the Enlightenment (Lefebvre, 1988), strived for equality, which in practice meant the abolishment of aristocratic privileges. They promoted a system wherein all men were equal before the law, and tax was paid on an equal basis. The nobility who held vast amounts of land, not to mention a superior status, refused to cooperate in the Estates-General beyond equality in taxation. They worked to maintain their superior social and economic status, as they denied Third Estate the public offices they held. Consequently, the Third Estate's demand for equality, which was far from limited to taxation, resulted in yet another conflict between the bourgeoisie and the nobility. In broad terms, it was a conflict between the preservation of the social order and the demand for a new one. In this light, Louis XVI's decision to side with the nobility becomes very understandable, even despite the prior animosity between them (Lefebvre, 1988).

At the end of the year 1788, the Résultat du Conseil was published, which was an act allowing the Third Estate an equal amount of deputies as the First and Second Estates combined. What was not clarified in the act was the specification of the voting system, i.e., whether it was to be voted per capita or per Estate. As expected, the Third Estate, who regarded themselves at the embodiment of "the nation" (Lefebvre, 1988), interpreted the Résultat du Conseil as voting per capita, as opposed to the Second Estate who opposed such an interpretation. Third Estate was informed that it was only granted one vote per Estate, instead of per-capita. Consequently, the Third Estate separated from the Estates-General and instead formed the National Assembly.

As the absolute monarchical structure still prevailed, Louis XVI's consent was required in order to create the new law. The King, whose position was in jeo- 
pardy, decided to close the Third Estate out from the meeting of the National Assembly. As a result, the deputies decided to move to the tennis court, where they swore an oath not to leave until a new constitution was formed (Lefebvre, 1988).

\subsection{The Bourgeois, Popular and Peasant Revolution}

The bourgeoisie was by no means a homogenous group, and this was perhaps most clearly reflected by the immense differences in wealth and social status. ${ }^{26}$ Since the bourgeoisie had gained significant economic advantages in trade, finance and industry as well as their purchase of land, many of them had, by the $18^{\text {th }}$ century, developed close ties with the nobility and the clergy (Lefebvre, 1988). However, the ties that the aspiring bourgeoisie had with the nobility was by no means indicative of homogeneity between the two groups. In fact, they were rather antagonistic toward each other. As a consequence of the gradually rising bourgeoisie, who were gaining increasing economic power and political consciousness, the nobility and the clergy, despite their socially privileged position, grew continuously weaker.

In regards to the general population, the vast majority of the French population were illiterate, but the French masses impatiently followed the developments of the events by attending cafes where the public would discuss the news and rumours that were being spread (Lefebvre, 1988, Chartier 1991, Hunt, 1984, Ozouf, 1991). Private correspondence among the Third Estate was one of the main sources of information that kept the public informed of the course of events. This gave the assemblymen a direct way to influence and shape public opinion that in turn gave rise to many protests (Lefebvre, 1988). The underlying cause of the uprisings throughout France in the year 1789 can be found in the economic crisis that resulted in inflation. Following the crisis, the famine worsened due to bad harvests, inefficient agricultural methods and transportation. The masses did not only demand bread, but also the reformation of taxation and an easing of the tax burden (Hobsbwam, 1996).

The peasants, who constituted at least three-quarters of the French population (Moulin, 1991), were by no means a homogenous group: there was a wealthy group of farmers who owned their land, then there were petty peasants, who did not own land, nor had enough to live off of. However, the legal status of peasants had improved dramatically by 1789 ; most peasants were liberated from serfdom and were free to work, own land and even the right to initiate proceedings (Lefebvre, 1988).

In the middle of the $18^{\text {th }}$ century, and at the end of the Ancien Régime, the economic and agricultural crisis in France had worsened which, in turn, led an increased fear amongst the peasants concerning the aristocracy and their intentions. This fear, La Grande Peur ${ }^{3}$, led to an increasingly defensive attitude among the peasantry, who were more inclined to take up arms and organize (Lefebvre, ${ }^{3}$ For further reading see Lefebvre, The Great Fear of 1789: Rural Panic in Revolutionary France, Princeton University Press, 1982. 
1988). Although La Grande Peur was a contributing factor, it was not the main cause of the uprisings. Lefebvre wrote that "to get the peasant to rise and revolt, there was no need of the Great Fear, as so many historians have suggested: when the panic came he was already up and away" (Lefebvre, 1988). The uprisings resulted in the abolition of serfdom and the formal abolishment of the feudal regime as well as the noble rights.

\section{The Declaration of the Rights of Man and of the Citizen and the March on Versailles}

As revolts were spreading throughout France, and as an attempt to restore the order, the National Assembly examined various constitutional drafts, and a declaration of civil rights. The National Assembly decided to first put forth a document that explained and clarified the rights of man and citizen. The idea was to set the basis for the development of a new constitution. As the main issue was the estates and the privileges they held, the aristocracy naturally tried to postpone the declaration by demanding a two-thirds majority, fearing that the declaration would strip them of their privileges, and dismantle the status quo that placed them above the rest of the population. The peasant revolt made it clear that the feudal proprietorship would not be able to sustain itself. The bourgeoisie proposed a compromise, in which the aristocracy was to receive a reasonable compensation for their ownership of land, but were to revoke, without compensation, any obligations of the peasants toward the nobility.

The creation of a constitution was now the main focus of the National Assembly. The negotiations were intense due to the differences amongst the deputies. The monarch still held a legislative veto power, and the National Assembly, which was situated in Versailles, expected that the decree would be approved by the King. The resistance expressed by the monarch was the main source of concern for the National Assembly, since if the decree and the Declaration were rejected, it would essentially mean the restoration of the Ancien Régime. The National Assembly could not force the King to sanction the August decrees, instead they needed the masses to exercise their power.

In the eyes of the French masses, the suspensive veto that had been granted to the King by the National Assembly was seen as an act of aristocratic conspiracy. Yet again, just as some months earlier, the aristocratic conspiracy was blamed for the food scarcity and the high bread prices. Not long after, in the beginning of October 1789, a group of women had gathered outside Hôtel de Ville in Paris to protest against the high price and scarcity of bread (Lefebvre, 1988). The women tried to get a hold of as much arms and ammunition as possible by taking various weapons from the Hôtel de Ville. As more people gathered, various activists and revolutionaries gathered to demand political reforms. The riotous atmosphere, the desperate need for food, as well as the fear of the aristocratic conspiracy led to the six hour march to Versailles. On the March on Versailles, seven thousand women walked to Versailles (Zancarini-Fournel, 2004). As they arrived in Versailles, the crowd gathered outside the palace and waited to be in- 
vited by King Louis XVI, to whom they wanted to present their demands; transportation of grain to Paris, and bread. Although the King promised to meet these demands, their attempts would prove fruitless. The situation continued to worsen, as the presence of royal troops increased. What the masses feared the most was that the King would dissolve the National Assembly, and lay waste to their reforms.

Due to immense public pressure, the King ratified the Declaration of the Rights of Man, which limited and undermined the power he held as the monarch. In order to make sure that the King would keep his promise and meet the demands of the people, they wanted to have their King in their midst. Consequently, the King moved to Paris and appeared to be at the service of the people. The National Assembly who had drafted and instituted the Declaration of Man and Citizen in August 1789, came to constitute the legal entity of the nation, and subsequently ended aristocratic rule through the abolishment of the feudal regime; political sovereignty was to rest in the hands of the nation.

\section{The Concept of Law}

One of the most significant instruments of social transformation, as well as the most important outcome of the revolutionary period, was the Declaration of the Rights of Man and of the Citizen, adopted by the French National Assembly, on 26 August 1789. The pragmatism of the Declaration is reflected by its definition of the fundamental principles of a new society and constituted the first step in the at least decade long chain of events, which we refer to as the French Revolution. Many, if not most, of the political reforms and civic rights we have today, were for the first time implemented during the French Revolution.

\subsection{The Drafting of the Declaration of the Rights of Man and of the Citizen}

The Third Estate, which at least in theory, represented twenty-four million people, needed to attend to the formulation of the Declaration of the Rights of Man and of the Citizen to ensure the continuation of the political development. The Declaration of the Rights of Man and of the Citizen was to lay the foundation for the constitution, which would be adopted two years later. The fundamental reasoning behind the formulation of two documents, as opposed to one, was to avoid the possibility of popular protest against the restrictions set by the National Assembly. In July 1789 the Constituent Assembly, assigned by the National Assembly to draft a constitution, proposed a draft of 24 articles. The main point of the Declaration was to attend to the issue of the veto, and whether it should be a matter of qualification or absolutism, as well as whether the form of legislation should be unicameral or bicameral. Essentially, the decision would determine the limits of royal power. Other than its main points, the National Assembly faced several other urgent issues, among them, the abolishment of Estates as well as the corresponding privileges granted to them, and the reforma- 
tion of taxes.

On August 12, the National Assembly began working on the Declaration of the Rights of Man and of the Citizen. When all the suggestions had been presented and debated, the idea was that the Declaration would be revised. However, despite the intention of a final revision, the unrevised version of the Declaration became the official one. The reason for this was the fact that the Declaration had already reached the people, who by then had given the Declaration an almost sacred status.

\subsection{The Declaration of the Rights of Man and of the Citizen}

The theory of critical legal studies requires the socio economic context in order to accurately analyse historical events. Without the appropriate historical context, the Declaration appears as a rather abstract gathering of principles. However for the members of the National Assembly, each article constituted a reaction against the reality in which they had lived (Lefebvre, 1988).

In order to facilitate the presentation and description of the articles, the main articles of the Declaration of the Rights of Man and of the Citizen will not be described chronologically, but rather presented under the four fundamental subjects; sovereignty and representation, universal claim of freedom and equality, economic freedom and the right to property, and tolerance and religion.

\subsubsection{Sovereignty and Representation}

The Declaration opens with the preamble stating that the National Assembly is the "representative of the French people". The representatives of the 24 million Frenchmen, most of whom were either peasants or labourers, were constituted by the members Third Estate who dominated the National Assembly. They were a group of passionate and well-educated men, who held positions such as merchants, estate managers, traders, shopkeepers, doctors and craftsmen, and above all, jurists (Lefebvre, 1988, Stone, 2004). The majority of the population represented by the Third Estate was the peasantry and the labouring poor who had proven to be a great revolutionary force. They expected their representatives to demand the will of the people, and thereby introduce legal reforms against the nobility and the clergy, who they held responsible for the poverty and misery they had faced for so long.

The Declaration was essentially an attempt to unify the will of the common masses as well as that of the bourgeoisie. Moreover, the Declaration aimed to abolish the Ancien Régime and commence the political process of a new society based on a new concept of governance. The Declaration as a whole must therefore be understood as a reaction against the Ancien Régime, where the source of law lay in the divine will, by virtue of which the divine monarch was the source of its own legitimacy and sovereignty. It was in the interest of the great majority, that the power never be abused as it had been during the Ancien Régime.

Article 3 states that sovereignty resides in the nation and that the general will 
of the people is the source of legitimacy in a sovereign statehood. The government's exercise of power should not occur in the interest of the ruler, but rather, in the interest of the ruled, and furthermore, that the rulers are subject to the control and power of the nation; "No body nor individual may exercise any authority which does not proceed directly form the nation". This confirms the rupture with the old notion of the Ancien Régime. In other words, at this point one is only required to obey the law, rather than an arbitrary monarch who forces his will upon his subjects. Thus, it becomes apparent that the concept of the nation is identifiable as its citizens. This confirms the idea within critical legal studies that the law on paper provides equality but in fact, as we shall see later, disregards the de facto inequality in reality.

Article 6 describes legal basis of popular sovereignty, as law being the expression of the general will. This question was raised by Montesquieu, who claimed that the laws of the organization of a community should be derived from the experience of the people, and not from the divine will. In his major work, The Spirit of Law (Montesquieu, 2011). He concluded that the constitutional monarchy was the best form of government, as opposed to a monarchy, a republic, or despotism. Rousseau, formulated this approach even more clearly in his work Social Contract where only the voluntary agreement of the individuals of the community constituted the legal basis. The fact that an individual voluntarily enters into the social contract means that the individual can preserve his original freedom. The state exists only as the embodiment of the general will, which must regularly be renewed and confirmed (Rousseau, 1997). The principle of popular sovereignty was crucial, since it would come to legally determine the extent of power and authority exercised over those who disagree with the representative of the state, i.e., the relationship between the ruler and the ruled. As article 6 states, the legitimate source of law was henceforth derived from the people, eliminating the privilege of the nobility and clergy. Furthermore, it stated that every citizen has the legal right to "participate personally, or through his representative", i.e., through direct or representative legislation. Whether the legitimate source of sovereignty resided in the legally elected body, the National Assembly, or the people, was unclear.

The individual rights brought up in articles 7, 8 and 9 further reinforced this notion of sovereignty stated in the third article. One of the main characteristics of the law during the Ancien Régime, was the principle of legality, or rather the lack thereof. The King distorted the interpretation of sections of the law according to his own will, which resulted in uncertainty and the abuse of legal process. These were the direct problems articles 7, 8 and 9 intended to overcome. As opposed to the arbitrary obligations of the Ancien Régime, individuals were now able to possess individual and civil rights. Beyond that, the monarch's power was further limited by article 15. It confirmed the end of the Ancien Régime's idea of the absolute and holy monarch, and instead gave rise to a constitutional monarchy, in which even the king could be held accountable.

\section{The universal claim of freedom and equality}


The fundamental philosophy behind the Declaration is presented in the first article, that of the universal right to freedom and equality. For the unprivileged masses that never possessed any rights, this development indicated a profound change of the societal structure.

Although the opening paragraph states that "Men are born and remain free and equal in rights", nothing is mentioned in the second article, where the inalienable rights are stated. The second article of the Declaration brings up the notion of the natural rights. It states that one of the "natural and imprescriptible rights of man" is "liberty". The Declaration's fourth article defines liberty very extensively, as "the freedom to do everything which injures no one else". It implies that it is not an absolute liberty, but rather a positive right to limit the freedom of someone when it injures someone else's. Thus, liberty consists of having the right to do everything that harms no one else, and these limits are, as stated in article 4 and 5 determined by law. In other words, the maximum collective liberty, is an optimal liberty for the individual. Another principle that the Declaration put forth, was the principle of equal opportunity, stated in the sixth article as, "All citizens, being equal in the eyes of the law, are equally eligible to all dignities and to all public positions and occupations, according to their abilities, and without distinction except that of their virtues and talents". In the light of critical legal theory this article also requires some historical reviewing in order to demystify the socio economic inequalities that indeed prevailed. Within the royal administration of the Ancien Régime, characterized by the aristocratic privileges, the positions and seats of government were given to those of noble birth. These high offices could be bought by the nobility, which led to the government, at this time, being the centre of attention for ambitious career-oriented nobles. These positions not only ensured economic and social status, but also power. Moreover, formal education was completely dominated by the hegemony of the Church and the clergy, which gave rise to a system that continuously produced educated men who were greatly influenced by Catholic teachings, men who, in turn, worked to maintain and justify the Ancien Régime. Equal opportunities meant that man was limited only by his virtues and talents, not by his birth.

\subsubsection{Economic Freedom and the Right to Property}

In the second article of the Declaration, ownership is valued as highly as liberty. There are no further clarifications on what constituted property. The principle of the right of ownership was not a new value. On the contrary, it was of great interest in the Ancien Régime, although, during this period, it was reserved for the clergy, the nobility, and the king. What distinguished the clergy and the nobility from the bourgeoisie was not the idea of the right of ownership, or the unequal distribution of ownership and wealth. What the bourgeoisie demanded, was that all, regardless of their status, were to have the right to own property.

In order to fully comprehend the main aim of the Declaration, the critical legal theory of these events focuses on the historical and social context which needs to be considered in order the demystify the reality beyond the written law. 
In the $14^{\text {th }}$ century, the bourgeoisie had assumed its role in the Third Estate in the Estates-General. Throughout the following two centuries, the position of the bourgeoisie had risen dramatically, partly as a result of the geographical exploration, and partly as a result of their economic support of the monarchy. The conditions of production during the Ancien Régime was mainly agricultural (Lefebvre, 2005), in which the majority of the surplus came from rent. The economic development in France during the second half of the $18^{\text {th }}$ century was stalled by the lack of advancements in industry, and as it did not yield as much income, agriculture remained the priority. Furthermore, the bad harvest in 1788 as well as in $\mathbf{1 7 8 9}$ had resulted in great difficulties for the French economy. The economy was in jeopardy, and at the same time there was a rapid growth in population. The peasantry was badly affected by the bad harvest since it had resulted in large producers selling grain at famine prices.

The bourgeoisie thrived throughout the $18^{\text {th }}$ century partly due to changes in production and commerce, resulting in a transformation from agricultural to industrial production. The changes on landed property, land tenure and agriculture were of great significance, and resulted in an increase in economic dependency on trade and industry. As expected from a critical legal point of view, the wealth of the bourgeoisie was increasing and, thus, so did their demands of political representation. The system of the First and Second Estate was growing weaker, whilst the nobility were losing their high social status, and clergy were being increasingly shunned. The bourgeoisie began to settle in its position of economic power, and consequently, the political power fell into its hands, something clearly reflected in the formation of the Declaration.

The concept of security, as stated in Article 2, developed within the bourgeois ideology as it was meant to ensure the protection of the individual, his person and property. But its significance also derived from the historical context in which it developed. The collective fear and concern that spread as a result of the aristocratic conspiracy, allowed for the realization of "security and resistance to oppression" as a natural right. This security was upheld by military forces for the good of all, according to Article 12. The masses and the bourgeoisie had unified in their struggle against aristocratic privileges. With this statement, the defence of the Third Estate against the nobility and the clergy was reinforced. The resistance to oppression was however directed solely toward the Ancien Régime, and would no longer be necessary in the future society.

\subsubsection{Tolerance and Religion}

The official religion of France was Catholicism and the pope, as the head of the Roman Catholic Church, was recognized as a high authority, despite the fact that the king practised considerable autonomy. The monarchy secured its authority of the clergy by the establishment of the First Estate, of which the clergy constituted at least 130,000 of its members (Greenbaum, 1967). Economically, the church was prospering, while the state was on the verge of bankruptcy. The explanation could partly be found in the fact that the church was exempt from tax- 
ation while it levied a tithe which was collected by the church. The position of power that the church held was not only economic. Most institutions were dominated by the teachings of the Catholic Church. Perhaps most important, is the fact that educational institutions were under the influence of the church, which in turn shaped, in the eyes of the church, a suitable conception of the world among those who had access to education.

The process of secularization had begun to develop already by the year 1789 . Public resistance was characterized by a strong anti-clerical sentiment. Furthermore, in terms of the philosophy of the Enlightenment, it meant the idea of rationality prevailing over dogmatic and irrational religious practices. In short, it was an indirect wish to sever ties with the hierarchical structure of the Ancien Régime and its ideology, which justified despotism.

Article 10 regards the freedom of religion and an indirect recognition of religious tolerance. Their formulation of the recognition of freedom of religion simultaneously sheds light on the limits of this freedom, stating that it is granted, as long as "it does not disturb the public order established by law". Most of the deputies of the Third Estate perceived religion as a symbol of the despotism of the Ancien Régime. Instead, they found that the philosophy of the Enlightenment had laid the foundations of rational thought. Moreover, in the preamble of the Declaration, it is stated "the National Assembly recognizes and proclaims, in the presence and under the auspices of the Supreme Being, the following rights of man and of the citizens". The majority of the population represented by the Third Estate, were followers of the Catholic Church, which wan intrinsic part of their identity. For the peasants and the labourers, there was a clear distinction between the wealthy church and the clergy on the one hand, and their religious beliefs and God on the other.

A little more than two months after the drafting of the Declaration, the boundaries between the state and the church were redrawn; the tithe was abolished and the National Assembly seized church properties. From then on, the nation was the supreme entity, and the church was subordinate the nation. This decision resulted in the development of a more centralized nation state.

\section{The Philosophy of the Enlightenment}

The "Enlightenment" refers to a dominant thought in Europe during the $18^{\text {th }}$ century. It was an intellectual movement with an immense societal impact. In the Age of Revolution, Eric Hobsbawm states that "of all the ideological changes [the enlightenment] is by far the most profound, though its practical consequences were more ambiguous and undetermined than was then supposed. At all events, it is the most unprecedented" (Hobsbawm, 1996). Analysing the Enlightenment from a critical legal perspective it does not constitute a homogenous philosophical school or doctrine, but rather, it should be seen as a movement in the development of modern intellectual thought. Its representatives sought to eliminate the shortcomings of the existing society, and above all they believed in 
progress and the gradual improvement of all mankind.

The basic elements of the Enlightenment can be divided into three subcategories; ideal of liberation, which is also a prerequisite for the two following; the utopian ideals, and the necessity of progress.

\subsection{Ideal of Liberation}

In an acclaimed essay, Was ist Aufklärung?, Kant defined Enlightenment as "man's emergence from his self-imposed nonage. This nonage is self-imposed if its cause lies not in lack of understanding but in indecision and lack of courage to use one's own mind without another's guidance" (Kant, 1784). Here, Kant refers to the Enlightenment as a duality of mankind; the enlightened man is he who liberates himself intellectually and does not need anyone to make use of his intelligence. Examining the issue from a critical legal perspective it can be state that the concept of liberation is not in itself a philosophical concept, but rather a practical legal concept. However, in the theoretical sense, it is defined as the liberation from judgement in regard to any external criteria of authority. The concept is negative in the sense that it rejects all authority and positive in the sense that man judges himself, or more specifically, he dares to know himself. In general, it can be argued that rationalism separated and thus liberated philosophy from the grasp of medieval theology (Goldmann, 2010).

Critical legal theory argues that even though the Enlightenment developed as a new movement, this does not mean that the liberation it promoted was in itself a new phenomenon. The Enlightenment provides the generalization of the idea of liberation. Its conversion into an ideal must be applied to all areas of theoretical and practical knowledge.

\subsubsection{Religion and Morality}

The first generalization of the idea of liberation was in the field of religion. Be that as it may, what is certain is that the first application of the idea of liberation outside the field of strictly philosophical or scientific knowledge consisted of what we refer to as Deism, in the attempt to free religion from the supernatural. It is the belief in the existence of a supreme God as the creator of the universe, but without revelation. This creator does not intervene in the world nor does he interact with the men nor determine their fate. A growing number of deists and also theists, atheists and libertines emerged as a result from the religious wars of the $17^{\text {th }}$ Century, between the relevant clashing conceptions of Christianity, Protestantism and Catholicism. During the late $17^{\text {th }}$ century, the idea of God is criticized and blamed for the intense religious clashes. The result for many was atheism or enlightened deism and theism.

When religion is freed and separated from the supernatural, morality also strives to free itself from religion, since, according to the Enlightenment, morality does not by necessity depend on religion. Mankind possesses an innate moral sense that allows us to distinguish right from wrong, good from bad and thus shape a moral idea of the world. The Enlightenment is indicative of certain ni- 
hilist tendencies, as there is no value judgement regarding morality. Furthermore, this development did not exclude the separation of politics from morality, something that has further been suggested in the Declaration of the Rights of Man and of the Citizen of 1789.

\subsubsection{Political Thought}

Charles-Louis de Secondat, Baron de Montesquieu ${ }^{4}$, sheds light on new political thought in France. Montesquieu states that virtue did not correspond to moral or Christian virtue, but rather to a political one, which, in turn, is defined by equality, and love for the republic (Montesquieu, 2011). The Montesquieuian virtue does however not exclude the existence of moral and Christian virtues, but rather, it affirms that they are not the main driving force of social life. Hence, what Montesquieu considered to be a good man, is not necessarily a good Christian, but a good political man, that is, a rational man who possesses love of the laws and the community (Montesquieu, 2011). Since the laws of the community are variable, they are also positive. In turn, since laws arise from political activity, politics becomes self-perpetuating, as it generates laws, which in turn influence politics. Although founded on reason and natural law, the ideal political life for Montesquieu is that of an autonomous and independent man that obeys and commands himself.

Rousseau further reinforces this whole approach in his famous political treaties "Of the Social Contract, Or Principles of Political Right". Therein, he states the theory of the state as a political organization of the social contract, based on the notion that the absolute ruler must bow to the general will, "the Sovereign is, as he has no other power than the legislature, the only means of laws and because laws are nothing more than the actual act of the general will, the Sovereign can only act when the people are gathered together (Williams, 2014). Moreover, through the hypothesis of the social contract, the common good or the political goal is freedom, and an egalitarian liberty, and the only acceptable religion is one whose dogmas are the belief in the sanctity of the social contract and laws introduced with consent of the general will.

The ideal of liberation, from a critical legal perspective, does and should not limit itself to politics. As politics was consequently separate from morality during the Enlightenment, the same can be seen regarding economics.

\subsubsection{Economics}

Economics was not an exception from the ideal of liberation. In a similar manner as religion was separated from the supernatural, and morality from religion, so was economics from politics. As opposed to the critical legal theory where the socio economic context shapes our understanding of the law and the world as a whole, the separation of the economic from the political, was expressed by Smith in "The Wealth of Nations". The doctrine presented in Smith's work, enhances the autonomy of theoretical economics, as it improves the systematization of

\footnotetext{
${ }^{4} \mathrm{~A}$ philosopher, politician and monarchist in awe of the English parliament.
} 
economics as a knowledge, but above all its practical autonomy, to ensure the achievement of the common good through economic activity, independently from politics (Fleischacker, 2004). Indeed, the "invisible hand" and the natural order determine that, although economic activity is intimately related to reasons of self-interest, the result is overall beneficial for all. It is therefore not necessary for politics to achieve the common good, on the contrary, its intervention hinders the natural development of economic life. Meddling from politics is therefore not necessary for the achievement of the common good, rather its intervention hinders the natural development of efficient economic life.

\subsection{Utopian Ideals}

The modern utopias were not an $18^{\text {th }}$ century invention, but rather originated during the $16^{\text {th }}$ century, and emerged as a literary genre in which the description of an unreal social organization, that served as a critical and constructive counterpoint regarding the actual political organizations. ${ }^{5}$ The Enlightenment however, applied, without any hinders, utopia into reality. One example of the utopian ideal was democracy, as was best described by Rousseau.

\section{Sovereignty and Democracy}

According to Rousseau, democracy is a political ideal due to its form of organization. He states that "where there a people of gods, their government would be democratic. So perfect a government is not for men" and furthermore, "there never has been a real democracy, and there never will be" (Rousseau, 1762).

The reason why democracy achieved the rank of an ideal for Rousseau is that it is the only form of government that fits perfectly with a state constituted by the general will. And in turn, the reason for why a true democracy could never exist, lay in the difference between sovereignty and the government. While sovereignty stems from the general will, it is impossible, however, that the government involves the active participation of all, but it is uncertain of whether it would even by a majority of the citizens. The tension between the sovereignty and the government is at the core of destruction;"the body politic, like the human body, begins to die from its birth, and bears in itself the causes of its destruction" (Rousseau, 1762). Thus, the purest democratic life is the moment it is born. After the point of its emergence, the decline begins.

The Rousseauian ideal is of a perfect preservation of democracy, and if the general will can be properly extended in the form of a government, the political body would be indestructible and eternal. The political organization is both a real and a utopian democracy. Only at the moment of the political liberation of the people does the democratic ideal become reality; and then the same idea becomes utopian.

Democracy is not the only utopian ideal for man: truth is another. The truth is exclusive to God and, in the most charitable of interpretations, an unattainable goal for man. But that does not mean that man can ignore it, but rather that his ${ }^{5}$ See for example Moore, Utopia. 
activity must be converted into an endless search for it. The plain truth is utopian to man, but the human mind is actually configured as an endless search for the truth that is lacking. Although, it is not within our reach it should not stop the stride for the ideal state, because, although never perfectly realized, the attempts and aspirations can produce positive results, such as an indefinite progress.

\subsection{The Necessity of Progress}

The belief in infinite progress (Gray, 2002) where anything is possible in the present is optimistic. It is an expression of the conviction that progress is connected to the intellectual progress of mankind (Schmidt, 1996). The development of nature and of man lies in progress. Since progress is indefinite, it becomes impossible to reach an end. Therefore, the idea of indefinite progress is inseparable from its failure.

\subsubsection{Criticism as a Method}

Criticism implies a considerate examination of a matter, and the subsequent judgement expressed according to the appropriate criteria such as good or bad, true or false. The results of criticism, considered as method and a tool in the quest for the truth, depend on the criteria that one sets up when judging. At this point, a distinction between classical and modern thought is necessary; The ancient and medieval criteria are universal and transcendent, that is, beyond the man who judges. On the other hand, for modern thought, the criterion is set by the subject that judges. In short, Man will establish criteria and apply them. In the words of one of the co-editors of the "Encyclopédie, ou dictionnaire raisonné des sciences, des arts et des metiers" ${ }^{\prime}$, which constituted the quintessential nature of the Enlightenment, D'Alembert described the characteristics of the movement as the following; "everything has been discussed, analysed, removed from the principles of science to the fundamentals of revealed religion" (Hanking, 1990).

\subsubsection{Process of Learning and Education}

The emphasis on the autonomous individual, who is freed from the imposition of authority during the Enlightenment, derives from the idea that man cannot blame anyone else but himself (Schmidt, 1996). The notion of Enlightenment is intrinsically linked with that of education and learning. At this point, a paradox in the practical aspect of the enlightened becomes apparent. It is part of the foundation of the definition of the Enlightenment thought that in every individual exists a natural desire for the development of one's own abilities. The logic of this approach leads to the idea that man has to liberate himself. Man must use his own judgement, because that independence cannot be mediated by dependence (Kant, 2003).

The Enlightenment thought coincides with the idea that man can only become

${ }^{6}$ First published in 1751 and edited by Diderot and D'Alembert. 
enlightened as a result of education, and that man is nothing more than what he makes of education (Kant, 2010). If we pursue this further, a necessary question arises, namely how can one individual teach another to be independent? It would subject the autonomous individual to the authority of an educator, similar to what happened with Christian education. Furthermore, it would turn man into a learner, and not an active and self-trained man with innate reason. It goes against the core principles of the Enlightenment; that of autonomy, the absence of authority, infinite progress and criticism, essentially the Sapere Aude! (Kant, 1784).

\section{Critical Legal Studies}

Historical developments and socio-economic transformations within a society change the dominant paradigms in various aspects of human life, such as in science, philosophy, religion and culture. The economic and political crisis in the French society at the end of the $17^{\text {th }}$ century was no exception. Indeed, the crisis had a profound impact on all aspects of social, economic and legal life. As the structures were changing and new social models were emerging, so were the perceptions of legitimacy, morality and justice.

The analysis of the socio-economic structure of society as well as its corresponding laws is central to the analysis of Critical Legal Studies (CLS) (Unger, 1983, Kelman, 1987). It is a transcontinental and diffuse movement that affects most aspects of social life. This interdisciplinary movement is not confined to one particular theory, but to various critical theories reflecting various ideological streams ${ }^{7}$, but all with one common denominator they critically analyse the prevailing legal norms, institutions and their corresponding relation to power.

This paper will analyze the events of 1789 from a $20^{\text {th }}$ century lens. The fundamental principles of CLS will therefore provide the analytical basis of the historical process that finally culminated in the Revolution of 1789 .

\subsection{General Characteristics of CLS}

At the end of the 1970's, an era marked by political activism ${ }^{8}$, a group of professors and scholars from various fields of humanities and law, held a conference to reveal the ideological prejudices of the mainstream legal philosophy. ${ }^{9}$ The main element of the critique of the legal system that is of central importance in this paper, is the critique against liberalism, as the French Revolution can be seen as the reinforcement of the liberal project.

The three main elements in the critique of the legal system that CLS aims to

\footnotetext{
${ }^{7}$ Various ideologies spanning from French Deconstruction, Frankfurt school, to radical feminism. ${ }^{8}$ An era marked by Vietnam War, Civil rights movement, feminist and student movements. See Tushnet (1991), Critical Legal Studies: A political History, pp. 1528, 1534, The Yale Law Journal, Vol. 17000, No. 5, Centennial Issue, March 1991.

${ }^{9} \mathrm{An}$ annual conference, Critical Legal Conference (CLC), established in 1984 is held in various countries. See Bauman (2002), Ideology and Community in the First Wave of Critical Legal Studies, p. 4, Toronto University Press, 2002.
} 
demystify are the hegemonic consciousness, the claim of objectivity and the prevailing contradictions and hierarchy (Trubek, 1984; Kennedy, 1998; Unger, 1976, Freeman, 1981). Yet another main element is that of legal consciousness, which is central in the analysis of this paper.

\subsubsection{The Hegemonic Consciousness}

CLS is a movement that rejects the notion of ius naturale and instead claims a critical dimension, focusing on socio-economic and political aspects, in the study of law. The statement "Law is Politics" (Kelman, 1987), confirms not only the belief that politics influences both legal norms and institutions, but rather that law functions mainly as a direct tool for the political elite to put in practise the subjective interest. In order for the socio-economic system to maintain and reproduce, it must be perceived as valid. The hegemonic consciousness determines the validity of the social order in a set of fundamental beliefs, concepts and values that are in turn accepted consciously or unconsciously by individuals and the institutions (Trubek, 1984; Kennedy, 1982). Duncan Kennedy, one of the most eminent figures of the CLS movement stated; "we all feel it [hegemony]. It's an aspect of all of our lives that we ourselves are trapped within systems of ideas that we feel are false, but can't break out of' (Kennedy, 1982).

One fundamental concept of liberalism as well as that of the French Revolution is the concept of rationality and the rational being, something emphasized both by the ideology of the bourgeoisie in 1789 as well as the philosophy of the Enlightenment. According to CLS the concept and definition of rationality is a belief determined by the hegemony and thus serves the interest of the ruling elite. The liberal legal system is therefore, according to CLS, illegitimate as it mystifies Reality (Bauman, 2002). The main goal of the CLS is to reveal the bias of the hidden agenda, by demystifying and thus revealing the subjective power interests behind the legal norms and institutions (Kelman, 1984).

\subsubsection{The Claim of Objectivity}

Although law and legal institutions might appear as fundamentally neutral and objective, they are a construction of social and economic aspects. Legal doctrine is not autonomous, nor is law isolated from the subjective and political values held by judges, legal practitioners. Instead, law constitutes the main instrument for oppression and alienation in society (Tushnet, 1991).

The fundamental idea behind the position that CLS bases its argument on is that there is no value-free, objective or neutral philosophical thought or political ideology. The very premise of rationality, individualism, and objectivity is rejected by CLS. More specifically, it rejects the claim of value-free legal order, objective decision-making regarding ethical convictions, policies or legal practitioners and institutions (Hunt, 1986; Unger, 1983).

The false objectivity hides the arbitrary legal rules, and thus mystifies the true condition of human life. The method applied by CLS to reveal the hierarchy as well as the subjective nature of law, is trashing (Kelman, 1984). It is essentially a 
methodological technique of delegitimization that questions and demystifies the power structure, as well as the perception that the prevailing legal structure is inevitable.

\subsubsection{Contradictions and Hierarchy}

According to CLS, liberal thought is based on dichotomies; between the public/private, formal/material, subjective/objective, and so forth (Trubek, 1984; Kennedy, 1998). These contradictions confirm the indeterminate and incoherent character of the legal system. The dualism forces a choice between two extremes in a hierarchical order.

The main example of these inconsistencies is the contradiction between the formal and material content of law. One of the main critiques directed towards liberalism is their emphasis on formal law, and the assumption that problems will be resolved merely through legislation, and thus disregarding the material aspects of the reality of life, such as economic inequality, etc.

Although formal legislation presents reforms that mitigate social pressure and require social change, it retains the basic values of the original structure, preventing any substantial change of the social and economic structure that CLS considers fundamentally unjust. In other words, as the formal law promises liberty and equality, it disregards the reality of oppression, economic inequality and hierarchy.

Another example is the formal, abstract and mechanical character of academic language and rhetoric and its relation to the content of law. In a similar manner as CLS emphasized the role of power relations in legal decision-making, so does legal speech, academic language, under the guise of formal rationality, legitimize and rationalize arbitrary interests.

As CLS regards law as a human product, it aims to increase the accessibility, participation and equality, by using informal, colloquial language (Kennedy, 1985). CLS attempts to deconstruct the formalism of legal discourse and thus reveal how academic language and other formal structures are used to subtly form the elitist hierarchical perception between the object and the subject. In the context of the French Revolution, which will be further discussed, the exclusion and inaccessibility of academic language became very apparent for the peasants as they spoke in the National Assembly in 1789.

\subsubsection{Legal Consciousness}

Another concept within CLS is that of legal consciousness. In order to comprehend the long and complex process that shapes the social, legal and economic conditions of a given society at a given historical moment, we must first recognize, even if only hypothetically, the existence of legal consciousness (Kennedy, 1980).

Within CLS, the multifaceted phenomenon of legal consciousness has not been uniformly defined. In this paper "legal consciousness" has been interpreted from an expanded view of a mass scale consciousness (Bauman, 2002), i.e., the perception of the law by members of society. The expanded view includes the 
form and the content of law, as well as the people's perception of legitimacy and justice; "legal consciousness includes all the ideas about the nature, function, and operation of law held by anyone in society at a given time" (Trubek, 1984). Legal consciousness translates notions that are disclosed within society, regarding the perception of legality and illegality, justice, duties and obligations in the relationship between men and the state. Moreover, legal consciousness is an expression of the evaluation of existing laws in society.

\section{Analysis and Final Discussion}

This paper adopts a CLS approach as well as a Classic historiographical perspective in the analysis of the historical events as well as the articles of the Declaration, since both theories have similar aspects such as the social and critical perspective of distribution of power and wealth. Moreover, both theories aim to reveal and demystify the disparity between the formal law and its material content. Furthermore, both theories regard law mainly as a regulatory tool to first and foremost implement the interest of the ruling elite.

The analysis begins with by analysing the universal claim of equality and freedom as expressed in the Declaration, followed by the economic structure of the French society and the economic rights presented in the Declaration. Lastly, the source of legitimacy will be analysed and discussed.

\subsection{CLS and the Universal Claim of Equality}

The disparity between the formal law and the material content is a central concept in CLS. What must not be ignored according to CLS is that formal equality before the law conceals the material inequalities that prevail in society.

In the social structure that followed the commencement of the French Revolution in 1789, the law enacted formal equality of all citizens before the law. However, as opposed to the Ancien Régime, where inequality was considered natural and ordained by God, the new law reflected openly the disparity between the formal and the material content of the law. In other words, society progressed from a socio-economic organization that legitimated inequality amongst citizens, to one that proclaimed objective equality. What distinguishes the events of 1789 and the French Revolution was the aspiration and proclamation of equality as its main objective.

As equality was the official proclamation of a Declaration, the reality must correspond to that aspiration, otherwise the rights have no real content according to CLS. The first paragraph of the Declaration uses the term "men" as a reference to all people, as opposed to "citizens", to express the universalist conception of natural law. An example of the disparity of the material content and the formal law is in place; the fact that the formal law claimed equality before the law was not coherent with the distinction of passive and active citizens. On this

\footnotetext{
${ }^{10}$ Article 6, The Declaration of the Rights of Man and of the Citizen.

${ }^{11}$ Article 9, The Declaration of the Rights of Man and of the Citizen.

${ }^{12}$ Article 1 , The Declaration of the Rights of Man and of the Citizen.
} 
basis, the terms "all citizens"10, "all persons"11, "men"12 appears misleading.

The proposition claimed that although members of a society should enjoy their civil rights, all should not have the legal right to actively influence public life. That right was reserved for those who actively contributed to the establishment, i.e., the active citizens. The term "passive citizen" was defined as a citizen who could not pay a minimum of three days of wages in direct taxation. This clearly stated that the right to actively participate in the political aspects of the public establishment was related to the economic wealth of the individual, since the amount of tax paid was related to the property owned. As a result, three social groups were excluded from actively partaking in the Republic, the public establishment and from voting; Children, women and free adult men whose income was below that of an active citizens (Le Cour Grandmaison, 1989). This narrow definition of the term "all citizens" and "all persons" contradicted the universal principle stated in theory.

The assemblymen reacted strongly against the ideology of the Ancien Régime. After centuries of an ideology influenced by Catholicism, where the position of man in society was seen as the expression of God's divine will, the new ideology emphasized the personal will of the individual as the determining factor of success. In the eyes of the deputies, poverty or unemployment was not a result of the prevailing socio-economic structures, but rather due to a lack of will power on the part of the individual. The individual was the only one to blame for his situation. Consequently, poverty was seen as the result of personal characteristics, or more specifically faults, such as laziness, ignorance, stupidity, immaturity, lack of discipline etc. Similarly, success and achievements were direct results of talent, ambition and hard work. Therefore, it would only be "right that those who contributed the most to the needs and maintenance of public institutions, should have a proportional share in its government" (Le Cour Grandmaison, 1989).

That poverty and unemployment was a personal choice presupposed that work existed in abundance and permanently for everyone. The deputies were convinced that the freedom stated in the Declaration guaranteed the free movement of men and, hence labour, resulting in an abundance of work. In the light of the CLS, the assemblymen, who disregarded social phenomena such as poverty and unemployment as a result of an essential unequal social structure and distribution of wealth, in turn, reproduced and maintained a fundamentally unequal society by the process of mystification of the law as well as the perception of society as a whole. Furthermore, the concept of active and passive citizens put the political power entirely in the hands of the ruling elite.

This unequal distribution of political power was further justified by certain principles of the philosophy of the Enlightenment. In terms of the philosophy of the Enlightenment, passive citizens, also referred to as the "the reasonless poor" (Le Cour Grandmaison, 1989), were considered as not yet fully developed into rational and enlightened beings. Passive citizens were in between the original natural state, where man was driven by emotions, and the enlightened and ra- 
tional state. Man was, if he truly desired, gradually progressing and gaining rationality. Siéyès, a clergyman and one of the most prominent member of the $\mathrm{Na}$ tional Assembly commented on this, stating; "Let the doors of good citizenship be always open to those men whom nature or circumstances make into real citizens, to set them apart from those that nature and circumstances mark with the brand of nonentity" (Le Cour Grandmaison, 1989). The underlying logic behind this thought is that man is not born a homo politicus, but rather that he can become one.

The distinction between passive and active citizens was further justified as it ensured that well-informed political decisions were made. However, informed decisions according to CLS are not objective by any means but rather protecting the arbitrary interest of the ruling elite. The political decisions taken were not only anti-aristocratic, but they also laid the foundations of the formation of a new society. The rational male proprietor alone possessed the legal right to discuss and determine national policies. Within the non-egalitarian political structure, the economic position and interest must not be disregarded. As the representatives of the French people possessed greater economic means than the people they represented, it appears only natural for them to have different interests to protect. For that reason, CLS emphasizes the necessity of the demystification and clarification of the distinction between the formal and material definition in order to be able to comprehend the meaning of the right to equality. The notion of equality in the Declaration referred to a juridical equality, and thus not a social or economic one. In other words, a distinction was made between equality in rights, and equality, or rather inequality, in wealth.

The formulation of a Declaration is by nature broadly formulated and thus gave room for misinterpretation. The masses were convinced that they had a legal right to demand equality and better conditions. The lack of clarification avoided a potential surge of discontent from spreading through the masses, of whom the majority barely possessed even the most modest economic wealth.

\subsection{CLS and the Universal Claim of Freedom}

Liberty is a positive right; the liberty to choose, act and think. However, the liberty as presented in the Declaration does not take into consideration the actual conditions that allow for options. This disparity between the formal and material law is, according to the Critical Legal approach, typical of liberalism. In this sense, if one does not have the economic or social possibility to choose between various options, the meaning of this liberty is futile. The formal value of liberty is then theoretical, entirely disregarding material conditions.

Article 6 in the Declaration of the Rights of Man and of the Citizen deals with equal opportunities. However, the individualist approach of this article merely scratches the surface of the issue of talent and ability. The article disregards the social and economic conditions that create the possibility for progress, such as education and training.

According to CLS approach, even though certain legal reforms or actions 
might appear as protecting the interest of the masses, the true underlying reason for them is to essentially protect the interest of the dominant elite (Bell, 1980). The freedom promoted in the Declaration was a political and economic one. And in its historical context it was crucial in the change of the social and political structure since freedom would enable the progress of the free market; freedom was needed to freely sell one's labour. The declaration thus reflected the necessity of the market, rather than being motivated by the idea of freedom for all men.

\subsection{CLS and the Economic Structure}

CLS emphasizes the importance of noting that political conditions between members in a society influence and are influenced by the legal conditions, which in turn are interlinked with the economic and material conditions. Legal consciousness sheds light on the very concept of justice and legality, and how these concepts relate to various economic premises. Furthermore, it presents the content of concepts, theories and legal doctrines as strongly influenced by the ideology of the ruling elite, such as the National Assembly, which was overwhelmingly dominated by bourgeois legal professionals.

\subsubsection{Transition of the Economic Base}

By the year 1789 the French feudal society was officially abolished, not only through legislation, but also through the subsequent developments in the economy. The bourgeoisie thrived throughout the $18^{\text {th }}$ century partly due to changes in production and commerce, resulting in a transformation from agricultural to industrial production. The changes on landed property, land tenure and agriculture were of great significance, and resulted in an increase in economic dependency on trade and industry. The wealth of the bourgeoisie was increasing and, thus, so did their demands of political representation. The system of the First and Second Estate was growing weaker, whilst the nobility were losing their high social status, and clergy were being increasingly shunned. In the light of CLS, as the bourgeoisie began to settle in their position of economic power they also came to constitute the ruling elite who mainly controlled or owned the means of production, and thus held the economic and consequently political and legal power in its hands, something clearly reflected in the interested protected in the Declaration.

\subsubsection{CLS and the Economic Rights in the Declaration}

In the Declaration of 1789, it becomes apparent that one of the main functions of law is to strengthen conditions of private property, and to present any limits to private property as a violation of state law. However, according to the Critical Legal approach, the Declaration does not take the unequal ownership of property into consideration and thus disregards the social reality. Moreover, the in violable right to property has been given an almost sacred value, and one of the apparent reasons for this can be found in the political construction of power 
centralization in the hands of the dominant elite. In other words, the National Assembly constituted a ruling elite made up educated men, who were often involved with commerce and trade and who actually had the means to purchase and own property.

Considering the socio-economic history of France, the unequal distribution of wealth and property, rights elevated to the status of natural rights, did not change the living conditions of the masses to the extent that it did the bourgeoisie. For the masses, of whom the majority did not own significant property, it becomes seemingly difficult to argue that they valued the right of ownership as highly as they did right to liberty, security and resistance to oppression.

The second article guaranteed great social progress, a progress in accordance with the philosophy of the Enlightenment; man was an individual and thus had the right to act and become what he wished. His limits were set by his talents (Hobsbawm, 1996). Theoretically, it was a claim for equality. However, due to the disparity between the formal and material law as emphasised by CLS, in practice the formal claim of equality appeared as an empty promise; considering that resources are limited, one individual's right to acquire property, also entails the right to accumulate it, thus excluding others from appropriating it. This individualist perspective was reinforced with the philosophy of the Enlightenment and the idea of the rational individual in the free market.

\subsection{CLS and the Philosophy of the Enlightenment}

In the light of the Critical Legal theory, the economic structure of a society is essential in relation to the process of economic production, since it influences and shapes the role of people, as well as their perception of society, either as an aggregate of its individual atoms (Hobsbawm, 1996) or as a collective unit. According to the classic economists, the Physiocrats, as a result of the individualist character of the market economy, within the free market individuals become reinforced autonomous elements, whose "motive force was their self interest and competition" (Hobsbawm, 1996). The development of the market economy was increasingly governed by the forces of supply and demand. Moreover, within the free market individuals acted rationally. The very premise of rationality is rejected by CLS. According to CLS, apparently neutral concepts such as that of rationality, is a belief determined by the hegemony and thus serves the arbitrary interest of the dominant elite. The Physiocrats however insist on the objective concept of rationality. According to them the rational man within the market economy would create a functioning market where an exchange of equivalents would ensure social justice, and thus, would not conflict with the general will. CLS criticizes this contradictory assumption, as the individual interest and the general will are not necessarily in harmony as Rousseau claimed, but at times are even conflicting. Even though the ruling elite attempts to appear as an objective representative and even protector of the interests of the masses, partly through hegemony, it is in reality acting merely to serve its own arbitrary interests.

Due to limited resources, the freedom to accumulate unlimited wealth hinders 
the development of material equality in the social, political and economic spheres. At this point, we are able to discern a correlation between the philosophy of the Enlightenment and the economic organization promoted by the bourgeoisie. More specifically, it reflects the relationship between the market economy, where the autonomous individual determines his actions, and the philosophy of the Enlightenment, where the absolute origin of an individual's actions and knowledge is derived from his individual consciousness.

The concept of the individual consciousness is central in the philosophy of the Enlightenment. According to this belief Man is no longer subjected to the authority of an absolute monarch or God. Instead, no authority higher than the individual's reason is recognized. It should be noted that the deputies subjected all institutions in society to the test of reason, and regarded private property, law and the state as the embodiment of reason. Although many of the philosophers regarded private property in this manner, Rousseau claimed that "the first man, having fenced in a piece of land, said "this is mine", and found people naïve enough to believe him, that man was the true founder of civil society. From how many crimes, wars, and murders, from how many horrors and misfortunes might not anyone have saved mankind, by pulling up the stakes, or filling up the ditch, and crying to his fellows: "beware of listening to this impostor; you are undone if you once forget that the fruits of the earth belong to us all, and the earth itself to nobody" (Rousseau, 2005).

Since the deputies meant that people were to be free from the subjugation of authority, and since they moreover were individuals with the ability to reason and act, neither poverty nor wealth was regarded as a potential consequence of any ensuing social structure. The philosophy of the enlightenment strengthened this view by stating "man's unlimited natural right to do as he liked" (Hobsbawm, 1996). If a man was wealthy or impoverished, it was not the result of a social structure, but rather the result of his personal qualities, or lack thereof. According to the theory of CLS this individualist perception further mystified the structurally unequal society by appearing essentially just and equal, since if man was poor due to laziness he could become rich and successful merely due to his will and talents. In other words, the problem was the individual not the structure.

\subsection{The Source of Legitimacy}

The economic structure prevailing in the Ancien Régime shaped the morality of society, which in turn had a practical value for the production: it legitimized and validated the social and economic structure through the process of hegemonic dominance. The legitimacy was derived from the divine onto the hands of the monarch. It was not to be questioned.

The secularization of society ended the notion of using morality based on religion, as a source of legitimacy. Naturally, this left a void regarding a new source of legitimacy. One of the problems of the Enlightenment was to find an objective 
basis for values, which in turn raises the question, from where did legitimacy derive if not from morality? In this light, it becomes easier to comprehend the new economic and social structure and the increasingly powerful and centralized state that emerged out of the French Revolution. The previous structure was being replaced, and the process of secularization and the creation of new laws and norms began.

\subsubsection{The Enlightenment Philosophy as the Source of Legitimacy}

Many principles of the Enlightenment are generally considered to have caused and shaped the French Revolution. Although this might be true to a certain extent, the perception of the Constituent Assembly regarding the good will of people was not necessarily as credulous as Rousseau deemed, nor did they agree with Diderot's understanding of the right of ownership (McKinley, 2008) or Rousseau's critique of representative democracy. Ultimately, in the light of CLS, the deputies of the National Assembly chose to implement aspects the philosophy that best corresponded to their arbitrary interests. Therefore, in a similar manner that religion and morality was used in the Ancien Régime to justify inequalities amongst people so were aspects of the Enlightenment philosophy used to implement ideas that protected the interest of the National Assembly, and to further justify legitimacy, and consequently produce obedience to the law, partly through the process of hegemonic dominance.

In the process of secularization, as well as that of the individualist ideology of the enlightened bourgeoisie, religion becomes a private matter. A religious man is thus religious privately, and acts rationally in a secularized society. Man's actions are not deemed sinful according to Christian values, but were measured according to profit or loss. In the secularized society, deprived of religious content, economic life was to become morally neutral. What determined human conditions was men's rationality in the economic life. CLS rejects the concept of neutrality in regards to rationality. Instead these values must be demystified in the process of trashing and thus be revealed as contingent and subjective (Trubek, 1984).

According to the philosophy of the Enlightenment and the process of secularisation, if individuals would act rationally, meaning that they would act in accordance with their self-interest, society itself would function satisfactorily. In this sense, there is a direct relation between the economic structure of a free market and its indifferent approach to morality as the source of legitimacy.

The assertion that the individual's own pursuit of happiness and satisfaction could also promote general good cannot be taken for granted since it assumes that the reason leading to general good is identical in all people. If man is concerned with his individual will, while simultaneously being concerned with the general will of society, he is divided in two contradictory parts, essentially becoming a Jekyll-Hyde being.

\subsubsection{Legitimacy through Representation}

The movement that leads to the French Revolution was not led by a formal party 
or one specific leader. At its core, the French Revolution derived from a popular movement. However, the Declaration opens with the preamble stating that the National Assembly is the representative of the French people. The representatives of the 24 million Frenchmen, most of whom were either peasants or labourers, were constituted by the members of the Third Estate who dominated the National Assembly. Most of the members of the Third Estate were a group of passionate and well-educated men, who held positions such as merchants, estate managers, traders, shopkeepers, doctors and craftsmen, and above all, jurists (Lefebvre, 1988). In the light of the Critical Legal approach, they constituted a socio-economic group that, in comparison to the masses it represented, held a privileged political status. ${ }^{13}$ The social interpretation of the Classic Historiographical School further reinforced this view of the bourgeoisie in 1789 as an ascending political class with socio-economic interests that differed from the masses.

The Critical Legal approach perceives legal reforms as essentially an act that further protects and reproduces the values of the ruling elite, even though they can appear as being essentially just and aimed to improve and protect the interest of the masses. This was apparent in the French Revolution. Although the revolution was not a consciously made plan that was put into practise by the bourgeoisie, the political and structural changes did however make it possible for the bourgeoisie to reach a more privileged political status. This sheds light on an interesting aspect; that the aspirations of active initiators of a movement do not necessarily become its beneficiaries. Therefore it would be a mistake to assume that because the bourgeoisie possessed a greater political and economic power, that they somehow consciously planned the outcome of the revolution. History is a dynamic and complex process, and such a conclusion would greatly undermine the force of the public movement that, motivated by hunger and fear, led to the storming of Bastille or the march on Versailles. Throughout the year of 1789 the masses constituted the driving force whose resistance was motivated by anti-feudal and anti-aristocratic aspirations, which carried the revolution forth. Lefebvre even went as far as to state that without the participation of the peasants, the revolution would not have been conceivable (Lefebvre, 1988).

This distinction between the Third Estate and the people they represented was not only apparent in economic terms, but also in social and cultural terms. Above all, they possessed the ability to speak a language that was incomprehensible to the common man. Thus, the formal language resulted in the exclusion of the majority of the unprivileged who had not undergone academic education and training. According to CLS, the inaccessibility of language is consciously used in order to create an exclusive sphere where the majority of the people are excluded from participation.

The bourgeoisie, who, in relation to the majority of the population, had considerably more property and wealth, promoted their will and influenced the

${ }^{13}$ The vast majority of the masses represented were, comprised of landless peasants and unskilled labourer who did not participate in the Third Estate or in the official political sphere. 
formation of the new society. In this manner, private interests enter the universal sphere of the state. However, this does indicate that the law is nothing other but the will of the ruling class, since it must be recognized that the Declaration had given legal rights that the people wanted and needed. The fact that they wanted other rights as well does not exclude that fact. At the same time, the situation for the majority of the population was so grave, and their needs so basic, that the amount of property they possessed was not enough for the articles regarding the right to property, to impact their lives in any significant way. On the other hand, we could also consider that the masses could have perceived the sacred right of ownership of property, as an active stand against the almost monopolistic ownership of land during the Ancien Régime. In the new society, ownership was not limited to those with a birthright to it. Instead, the opportunity for ownership was available to anyone, at least in theory.

Article 3 states that sovereignty resides in the nation and that the general will of the people is the source of legitimacy in a sovereign statehood. The government's exercise of power should not occur in the interest of the ruler, but rather, in the interest of the ruled, and furthermore, that the rulers are subject to the control and power of the nation; "No body nor individual may exercise any authority which does not proceed directly form the nation". This confirms the rupture with the old notion of the Ancien Régime. In other words, at this point one is only required to obey the law, rather than an arbitrary monarch who forces his will upon his subjects. Thus, it becomes apparent that the concept of the nation is identifiable as its citizens. This becomes problematic for two reasons. Firstly, on the basis of the philosophical claim of universalism of natural law as well as the Enlightenment principle of individualism, which contradicts the idea of citizens and nations, and secondly, on a material basis.

Firstly, the understanding of the role of the new citizen, as being the beneficiary of the Declaration of rights, is based, by definition, on the existence of a nation and the formulation of citizenship, i.e., citizens and non-citizens (Wallerstein, 2003). The philosophy of natural law, where law is understood as natural and eternal, goes against notion of a nation, which is territorially restricted, and also only reserves rights to citizens of that territory. Furthermore, the principle of individualism, and of the nation as the embodiment of the will of the people, appears paradoxical. The autonomous individual determines his actions and according to the philosophy of the Enlightenment as well as the ideology of the bourgeoisie, man, freed from the authority of the sacred king or holy God, only recognizes the authority of his own reason. Therefore, if ever in conflict, the will of the individual must, by necessity, go before the will of the nation as a collective of individuals. This is further supported by the economists, the Physiocrats, who claimed that due to the individualist character of the market economy, the individual becomes an even more autonomous element where its motive force was their self interest and competition. As one of the fundamental principles of the philosophy of the enlightenment is that of the autonomous individual guided by his innate reason, it set the basis for the economic system of a free 
market promoted by the Physiocrats, in their attempt to claim economics as an objective science. In turn, terms such as "self-interest", "rationality", "competition" appeared as apparent and obvious characters of human nature. Therefore, it could be claimed that the prevailing philosophy further promoted and maintained the free market, through hegemonic domination.

Secondly, a distinction must be made between a nation and its people, simply due to the fact that the will of an individual in a society does not always correlate with the will of its state or nation. The National Assembly determined the formulation of the Declaration. It should be noted that the National Assembly was not elected democratically, yet was still considered, at least by the deputies themselves, as an adequate representation of the people, however, in reality, this form of representation elevated the deputies over the people. As the vast majority of those represented by the Third Estate were poor, illiterate, and thus isolated from the political life, they depended entirely on the Third Estate for the representation of their interests. As a result of this, a great social and economic gap developed between the representatives, and those they represented. Although most of the radical forces came from the peasants and the labouring masses, and though they agreed with their bourgeois representatives regarding the anti-aristocratic agenda, they had other urgent matters that needed to be addressed, such as their overwhelming poverty, which, comparatively, was of less concern to the wealthy bourgeoisie.

The principle of representation was condemned by one of the more radical philosophers, Rousseau who stated that "sovereignty cannot be represented for the same reason that it cannot be alienated; it consists essentially of the general will and will cannot be represented. Any law that the people personally has not ratified is invalid; it is not a law" (Rousseau, 2010). The deputies of the National Assembly who were primarily inspired by the Enlightenment and to a great extent by Rousseau, paid little attention to Rousseau's criticism. This indicated that the bourgeoisie although inspired by the enlightenment movement, were not by necessity shaped by it. They held beliefs that they chose and within the Enlightenment philosophy promoted those thoughts they agreed with or that protected their interests as a group, which is coherent with CLS principle of the ruling elite acting in their subjective interest.

\section{Conclusion}

The French Revolution in 1789 was undoubtedly one of the most unprecedented events of Western intellectual history. Its uniqueness was best expressed in the ascending role of the bourgeoisie, the drafting of the Declaration of the Rights of Man and of the Citizen, and the Philosophy of the Enlightenment. All of which determined and were influenced by the economic structure of that same era.

The historical developments of the French Revolution prescribed the historical socio-economic basis for the reaction against the Ancien Régime. The representative organ, the Estates-General, maintained and reproduced the feudal system, proving incapable of reformation, indirectly led to the four revolutions that 
together constitute the French Revolution; The Aristocratic, Bourgeois, Popular and Peasant Revolution.

The Aristocratic revolution was the first revolution to emerge as a result of the monarchy's taxation of the privileged aristocracy. The monarchy and the aristocracy further strengthened the position of the Third Estate by excluding it from the Estates-General. The exclusion led to the formation of the National Assembly dominated by the Third estate and the formation of the Declaration of the Rights of Man and of the Citizen, and thus resulting in the Bourgeois Revolution. The reaction against the Ancien Régime also united the labourers and peasants who in turn revolted, resulting in both the Popular as well as the Peasant Revolution.

The main legal document of the year 1789, The Declaration of the Rights of Man and of the Citizens, not only led to the official abolishment of the feudal regime, but also left a legacy to the world; it defined the fundamental principles of a new society created by the Revolution and proclaimed inalienable rights of man and citizens; the universal right to freedom and equality, security and resistance to oppression and announced the sacred right of property.

The theoretical premise of the Declaration as well as that of the bourgeois Third Estate was inspired and influenced by the Philosophy of the Enlightenment. The ideal of liberation, utopia and progress were coherent with the social and economic alternative represented by the progressive bourgeoisie.

The bourgeoisie in 1789 dominated the political as well as economic and social sphere of the French society. The Critical Legal approach taken in this work emphasizes the importance of analyzing and revealing the legal institutions, law and its practitioners and their corresponding relation to power. The contradiction and disparity between the formal and material law are continuously mystified in the process of neutral and objective claims and furthermore maintained and reproduced in the hegemonic dominance.

The universal claims of freedom and equality and the economic rights in the Declaration, which in turn were inspired by the philosophy of the Enlightenment, safeguarded the economic interest and dominance of the bourgeoisie, as it facilitated the transition from a mode of production based on landed property to an increasingly free market where the supposedly objective forces of supply and demand prevailed.

A relationship between the rights protected in the Declaration of the Rights of Man and of the Citizen and the economic structure of the French society in 1789 prevailed. The source of legitimacy was derived from the aspects of the philosophy of the Enlightenment that best protected and maintained the arbitrary economic interest of the bourgeoisie as the dominant elite.

The aspiration of the bourgeoisie is best expressed in the Declaration of the Rights of Man and of the Citizen. The laws presented in the Declaration are objectively expressed as the will of the whole society, which in turn, mystifies the perception of reality. As a result, the organization of society seems to be the product of established objective laws, instead of the law being, perhaps not a di- 
rect product, but at the very least, influenced by the subjective interests of the lawmaker, i.e. the bourgeoisie.

The Declaration, as well as the deputies, promoted a strong belief in constitutionalism, as opposed to a purely egalitarian and democratic society. In fact, as the socio-economic and legal distinctions amongst the French citizens were disregarded, yet another division amongst men was introduced, that of passive and active citizens, as opposed to privileged and unprivileged, which was the prevailing social structure in the Ancien Régime. The ruling bourgeoisie had centralized the power and influence over politics in its own hands. It further reinforced its economic, and consequently, its social position through legislation regarding, for example, the right to property and the security of that property. The fact that the right of property was as sacred as liberty only confirms this fact, as it was a right that foremost met the interest of the property-owners.

The law functions as a system of mandatory rules, regulating the conduct of men. For the imposing rules to be valid and consequently obeyed, they must also be regarded as legitimate. The source of legitimacy of the essentially unequal social and economic structure was primarily derived from the Philosophy of the Enlightenment; its almost nihilistic approach to morality, its claim of objectivity, its deep belief in the individual and his consciousness as the source of progress. Moreover, not all aspects of the Enlightenment were adopted; only those who best served the economic interest of the bourgeoisie. ${ }^{14}$

The educated and political bourgeoisie who dominated the National Assembly, were strongly influenced by the ideas formulated by the enlightenment philosophers and the Physiocrats as it best served their economic and social interests. In this regard, a close relationship between the economic structure promoted by the bourgeoisie, the legitimating philosophy of the enlightenment, as well as that of the classical economists prevailed.

New social relations do not necessarily appear static or as a direct result of economics. As the transition into an increasingly free market was a process that started to occur in the feudal structure, the historical events of 1789 must therefore be understood as the beginning of the formation of a social structure that had not yet been fully shaped. This does not mean that aspirations of a new society had not emerged, but rather that they were not yet deeply rooted.

A strict correlation between the economic structure on the one hand and the legislation, prevailing philosophy, and the mentalities of the masses on the other, cannot be determined at this point. However, in broad terms the centralization of power in the hands of a king, or in the formation of a state, influences and shapes the legal system to a certain extent. Laws are, in this respect, political and thus subjective since they function as a regulative tool used to realize the will of, either a king, a National assembly or a centralized state.

That being said, it does not mean that the sole function of the superstructures,

${ }^{14}$ One example being the Grecian ideal of direct democracy defended by Rousseau, which was replaced by the idea of representation as it centered the political power in the hands of the National assembly and thus excluded the commoners represented from the political sphere. 
may it be philosophy or law, is to justify a political or economic cause, or passively implement laws that safeguard the interest of the ruling elite. However, it should be taken into consideration that the development of law is a continuum, and its process must be understood within the context in which it develops. Moreover, legal theories used to interpret the development of philosophical thought, also reflect, to a certain extent, the historical era and the social conditions that prevailed at that given time. When law is recognized as the product of man, it cannot be understood only as an objective and neutral phenomena isolated from society.

\section{Acknowledgements}

The author would like to express her gratitude to the faculty of Tsinghua School of Law for their invaluable comments, unwavering support and patience. In addition, a deep sense of gratitude to my parents, Babak and Mahin, for their encouragement and inspiration.

\section{Conflicts of Interest}

The author declares no conflicts of interest regarding the publication of this paper.

\section{References}

Bauman (2002). Ideology and Community in the First Wave of Critical Legal Studies. Toronto: Toronto University Press. https://doi.org/10.3138/9781442675964

Bell, D. A. (1980). Brown v. Board of Education and the Interest-Convergence Dilemma. Harvard Law Review, 93, 518-534. https://doi.org/10.2307/1340546

Chartier (1991). The Cultural Origins of the French Revolution. Durham, NC: Duke University Press.

Cobban, A. (1999). The Social Interpretation of the French Revolution. Cambridge: Cambridge University Press. https://doi.org/10.1017/CBO9780511622243

Fleischacker (2004). On Adam Smith's Wealth of Nations: A Philosophical Companion. Princeton, NJ: Princeton University Press.

Freeman, A. D. (1981). Truth and Mystification in Legal Scholarship. Yale Law Journal, 90, 1229-1237. https://doi.org/10.2307/795950

Goldmann (2010). The Philosophy of the Enlightenment. Abingdon-on-Thames: Routledge. https://doi.org/10.4324/9780203854303

Hanking (1990). Jean D'Alembert-Science. Oxford: Oxford University Press.

Heller (2009). The Bourgeois Revolution in France, 1789-1815. New York: Berghahn Books.

Hobsbawm (1996). The Age of Revolution 1789-1848.

Hunt (1986). The Theory of Critical Legal Studies. Oxford Journal of Legal Studies, 6, 1-45. https://doi.org/10.1093/ojls/6.1.1

Hunt, L. (1984). Politics, Culture and Class. Berkeley, CA: University of California Press. Kant (2003). On Education. Mineola, NY: Dover.

Kelman (1984). Trashing. Stanford Law Review, 36, 293-348. 
https://doi.org/10.2307/1228685

Kelman (1987). A Guide to Critical Legal Studies. Cambridge, MA: Harvard University Press. https://doi.org/10.2307/1372599

Kennedy, D. (1980). Toward a Historical Understanding of Legal Consciousness. Research in Law and Sociology, 3, 3-24.

Kennedy, D. (1982). Antonio Gramsci and the Legal System. ALSA Forum, 6, 32-39.

Kennedy, D. (1985). Spring Break. Texas Law Review, 63, 1377-1424.

Kennedy, D. (1998). A Critique of Adjudication. Cambridge, MA: Harvard University Press.

Le Cour Grandmaison (1989). Passive Citizens or the Reasonless Poor during the French Revolution, 1789-1791. The Language of Revolution, Italy.

https://ir.vanderbilt.edu/handle/1803/7171

Lefebvre (1962). The French Revolution: From Its Origins to 1793. New York: Columbia University Press.

Lefebvre (1988). 1789 Franska revolutionens bakgrund och orsaker. Demokratiskt biblioteket, Ordfronts förlag.

Lefebvre (2005). The Coming of the French Revolution. Princeton, NJ: Princeton University Press.

McKinley (2008). Illegitimate Children of the Enlightenment: Anarchists and the French Revolution, 1880-1914 (pp. 110-111). New York: Peter Lang Publishing.

Montesquieu (2011). The Spirit of Laws. Cosimo Classics.

Moulin (1991). Peasantry and Society in France since 1789. Cambridge: Cambridge University Press.

Ozouf (1991). Festivals and the French Revolution. Cambridge, MA: Harvard University Press.

Rousseau (1762). The Social Contract or Principles of Political Rights. Book III, IV. Democracy. http://www.constitution.org/jij/socon 02.htm

Rousseau (1762). The Social Contract or Principles of Political Right. Book III, XV, Deputies or Representatives. http://www.constitution.org/jir/socon.htm

Rousseau (1762). The Social Contract or Principles of Political Rights. Book II, 1. That Sovereignty Is Inalienable. http://www.constitution.org/jir/socon 02.htm

Rousseau (2010). Social Contract. New York: Simon and Schuster.

Schmidt (1996). What Is Enlightenment? Berkeley, CA: University of California Press.

Sée (1925). La France économique et sociale au XVIIIe siècle (pp. 14, 47, 65). Paris: Libraire Armand Colin.

http://www.herodote.net/Textes/see france economie XVIII.pdf

Stone, B. (2004). Reinterpreting the French Revolution: A Global-Historical Perspective. Cambridge: Cambridge University Press.

Trubek, D. M. (1984). Where the Action Is: Critical Legal Studies and Empiricism. Stanford Law Review, 36, 575-622. https://doi.org/10.2307/1228692

Tushnet, M. (1991). Critical Legal Studies: A Political History. The Yale Law Journal, 100, 1515-1544. https://doi.org/10.2307/796697

Unger (1976). Law in Modern Society. New York: Free Press.

Unger, R. M. (1983). The Critical Studies Movement. Harvard Law Review, 96, 561-675. https://doi.org/10.2307/1341032 
Wallerstein (2003). Citizens All? Citizens Some! The Making of the Citizen. Comparative Studies in Society and History, 45, 650-679.

https://doi.org/10.1017/S0010417503000318

Williams, L. (2014). Rousseau's Social Contract: An Introduction. Cambridge: Cambridge University Press.

Zancarini-Fournel, M. (2004). La place de l'histoire des femmes dans l'enseignement de l'histoire. Revue D'histoire Critique, 93, 63-78.

http://chrhc.revues.org/1289 